\title{
Testing the impact of fiscal policies for economic recovery: does monetary policy act as catalytic tool for economic Survival
}

\author{
Baihua Yuan $^{1} \cdot$ Wang Leiling ${ }^{2} \cdot$ Hayot Berk Saydaliev ${ }^{3,4} \oplus$. Vishal Dagar ${ }^{5}$. \\ Ángel Acevedo-Duque ${ }^{6}$
}

Received: 17 November 2021 / Accepted: 13 January 2022 / Published online: 15 February 2022

(c) The Author(s), under exclusive licence to Springer Science+Business Media, LLC, part of Springer Nature 2022

\begin{abstract}
This study seeks to evaluate the efficacy of macroeconomic revamping policies operationalized after the pandemic by fiscal and monetary regulators to fight the pandemic in China. This study aims to assess what the Chinese economic recovery implies after the pandemic regarding economic expansion and energy consumption of different economies utilizing an econometric approximation relying on data throughout the COVID-19 phase. Within the extended stage, Chinese economic development spillover impacts attain the same effect on upper-middle-income nations' economic expansion of 0.18 percent, next to the economic development, of lower-middle-income countries of 0.15 percent and high-income nations. We discover proofs of robust direct provincial spillovers, implying that provinces tend to construct a cluster of high-performing and low-performing areas, a procedure that accentuates regional earnings variances. Applying the experience of revamping previous financial crisis, we replicate the impact of the pandemic on the competence of these, and by far, other upper limit income nations to build back better from the pandemic to jobs occasioned by proofs of the pandemic. The spillover impact of China's economic revival past the pandemic phase's carries a critical effect on the expansion in energy consumption in high-income nations, subsequently middle-income nations. As total factor productivity headwinds underpin economic growth, fiscal policy is the only policy that probably sustains the pollution intensities and concurrently advances household well-being regarding consumption and jobs.
\end{abstract}

Keywords Fiscal policies $\cdot$ Monetary policy $\cdot$ Economic recovery $\cdot$ Econometric estimation · China

Wang Leiling

wangleiling@zzu.edu.cn

Extended author information available on the last page of the article 


\section{Introduction}

The economy witnesses a complete crisis, like the one throughout the pandemic, alongside government, aggregated debt at an alarming level, central banks operationalizing traditional monetary policies in a zero reduced bound ecology. At the same time, the macroeconomic impacts of these policies can't be evaluated within the environment of conventional macroeconomic models. Within this research piece, we examine fiscal policy interplay within a phase that comprises the world's financial crisis of 2008 as well as an aspect of the pandemic crisis (Ozoike-Dennis et al. 2019) and (Hilbers et al. 2019). To do this, we ease the presumptions that policy situations are rigid and take (Azad et al. 2021) to approximate interest percentage regulations for monetary policy and tax regulations for fiscal policy that varies randomly among dual regimes (Yildirim and Onder 2019) and (Geghamyan and Pavlickova 2019). Next, we apply a novel structural vector autoregression equation, suggested and used to examine the impacts of fiscal (Zaytsev 2020). For example, the value of 83 billion US dollars was formulated to aid job seekers who witnessed a fall in earnings owing to the coronavirus, by giving a subsidy to cover aspects of employee remuneration (Jinjarak et al. 2021).

COVID emergency fund for example, Canada Emergency Response Benefit (CERB), the amount of $\$ 83 \mathrm{~B}$, was formulated to assist those who are not working due to the pandemic correlated activities and those who exhausted their regular employment Insurance benefits, while the total quantum of \$23B was devoted to give earnings to assist those working and self-employed Canadians explicitly impacted by the pandemic plus those not eligible for employment income (Sarkodie and Owusu 2020). The implementation of monetary policy might vary across nations regarding their economic circumstances throughout the ongoing COVID-19. (Heyden and Heyden 2021) contended that the performance of monetary policy by the developing countries in reaction to the pandemic might not be efficient due to over volatility in exchanges rates and capital movement. But, developing countries can implement an amalgamation of inflation managing approaches and macroprudential instruments plus forex reserve aggregation as their policy models to manage the variations in capital movement and exchanges rates (Wei and Han 2021).

Considering that this policy framework encourages stability in the financial sector, the emerging countries can implement similar policies to react to the disruptions caused by the pandemic (Mosser 2020). The nations with huge forex reserves can manage their currency devaluation by interrupting their foreign exchange market circumstances (Lang and Schadner 2021). Since the pandemic correlates with reduced inflation in developed nations, growth monetary policy could encourage high-level economic expansion and financing. The world's monetary policy and its headwinds significantly ascertain circumstances. Expectedly, the implementation of monetary policy in the industrialized countries impacts the developing countries; monetary policy actions. (ElFayoumi and Hengge 2021). Further, the purposes of trade and investment globalization engender headwinds diffusion plus causes anxiety about a financial pandemic. 
As a result, the efficiency of the domestic monetary policy will rely on headwinds spread across industrialized countries (Victor et al. 2021).

So, the crude oil markets can see adverse supply and demand downturns throughout the pandemic phase. The cuts in the workforce supply, travel bans, and interruptions in transport plus business, explicitly and implicitly, led to an adverse supply interruption. The adverse demand slump is occasioned by economic challenges and the interruption of global value chains, limiting crude requirements. (Goldstein et al. 2021). These adverse headwinds on the crude limit global spending and financing. Many studies have attempted to tackle the impacts of the pandemic on crude costs (Goldstein et al. 2021), (Truger 2020), and (Pogorletskiy and Pokrovskaia 2021). Azad et al. (2021) confirmed that the pandemic adversely impacted the energy industries. Itani et al. (2020) noted that market doubts could forecast energy market vulnerability. Shaharuddin (2020) discovered that the pandemic cases and deaths expanded crude vulnerability and significantly influenced crude costs. Also, (Masud 2020) noticed a direct correlation between the net crude importation and exporting nations.

Likewise, crude is one of the main parts of the production process. The fall in crude costs limit generation costs and grow economic expansion (Tian 2021). Hence, declining crude costs were gainful for net crude importing nations. Contrarily, net crude exporting countries observed a dire cut in crude revenue, resulting in current account unsustainability and indebtedness. Crude oil-exporting nations witnessed a steep decline during an economic slump throughout the pandemic (ElFayoumi and Hengge 2021). Within this study, we keep on a path of present researches, comprising of (Faria-e-Castro 2021) and (Jinjarak et al. 2021) and (Lee et al. 2020) evaluated fiscal-monetary policy relationships in China.

Our contribution lies in the following aspects. (i) We are encouraged by the unparalleled substantial social, fiscal support given by the Chinese government and the traditional and nontraditional monetary policies employed by the government of China. We discover that fiscal policy has been extra potent than monetary policies and that deficit expenditure assists in increasing consumption plus productivity within the short term. (ii) But, the direct impacts on economic activity truncated with the passing of fiscal packages. Moreover, an increase, financing cuts, and inflation increase, causing challenges for an inflation controlling monetary policy regulators. (iii) Within the context, the research is devoted to evaluating the effects of China's economic recovery after the pandemic on economic expansion in different nations via spillover impacts. (iii) This, we relied on a huge data of empirical findings of 24 nations and the European Union territory from 199 to 2016 to anticipate the effect of Chinese economic recovery expansion of different nations. This is particularly relevant to the world economic build-back better plan after the pandemic.

The structure of the paper is as follows; Sect. 2 describes literature review, Sect. 3 data and methodology, Sect. 4 results and discussion, while Sect. 5 concludes the study. 


\section{Literature review}

The non-expansive nature of the literature depicts that financial markets have responded to the pandemic. Nonetheless, it equally affirms an upsurge in new cases, fatalities, and policy releases and actions to produce significantly low investor confidence in the economy. Whereas accentuating the pandemic circumstance implies drastic declines in economic growth in the future, financiers don't accurately estimate the financial consequences of strengthening or reducing the diffusion and pace of the pandemic. The pandemic researches synopsis aforementioned illustrates the poor are extra likely to change their attitude. Our analysis of strong direct regional spillovers shows increases in regional earning disparities, implying attitudinal variations in the form of social distancing potentially vary among the regions, creating additional issues for regulators to reduce the diffusion of the virus (Mitha 2020). The analysis stated in this study, whereas they cannot predict the course of action of the pandemic will assume, do give financiers some cues on the period pathway of economic build back better when the pandemic subsides, hence assisting in allocating their financing within the time and between asset types. So far as we know, it is a first of its kind to undertake an analysis to analyze the effect of the pandemic breakouts on real economic activity at the provincial level (Taghizadeh-Hesary and Taghizadeh-Hesary 2020) and (Taghizadeh-Hesary and Yoshino 2015). Thus, our analysis is different regarding its scientific contribution and direction on real economic activity analysis, applying the regional capturing of spatial spillovers among regions (Elyassi 2021).

The endurance of the corporate sector is equally connected closely to the length of the pandemic's headwinds. The external healthcare emergence is shortlived (Camous and Claeys 2020). Ultimately, the vaccines or a potent treatment will be developed, or the pandemic will last for some time, and the path traveled by the pandemic will fade off. Nevertheless, the timeframes for the pandemic to die off are uncertain and not predictable. Thus, the duration of the pandemic continues to be an essential type of uncertainty for the world. As the pandemic continues to linger on, the difficult it will be for enterprises to survive since their profits are impacted negatively and their performance. (Azad et al. 2021). So far as the shock persists beyond a specific phase of time, a sizable number of (Taghizadeh-Hesary and Yoshino 2019) (Taghizadeh-Hesary and Yoshino 2020) enterprises will survive and become profitable. Thus, its net value will be explicit as the economy recovers from prior-pandemic levels (Gao et al. 2021). Nevertheless, not all enterprises can live through an elongated pandemic with extensive lockdowns as well as management measures. Whereas industries will go through the headwinds and become viable, the same can't be said concerning single or man enterprises. Those who endure the COVID-19 might be significantly impacted, perhaps customers leaving or business units closing down, as well as might in reality required to adapt their business models to become viable in the aftermath of the pandemic world (Itani et al. 2020).

The heavy burdens that the COVID-19 outbreak has placed on the globe have been borne not only by the enterprises themselves nonetheless instead by all 
stakeholders. Indeed, the COVID-19 has interrupted a lot of economic interactions. The coronavirus impacted enterprises experienced a fall in their revenues. Stakeholders of companies adversely affected by the pandemic have lost a more significant proportion of their earnings. So, after several distributors deferring receivables, labor has been laid off or agreed to wage reductions. (Song and Zhou 2020). Borrowers have bargained their debts; however, if companies begin to renege on their payment levels, they are likely to be forced into insolvency. To eschew the circumstance, credit in the type of rollover of settlements coming due plus new investment would assist (Mohsin et al. 2021b) and (Wang and Zhang 2021).

Present crises determination instruments and bankruptcy codes, relooked after past financial crises, are not formulated to give such aid to hard-hit companies surrounded by an external systemic headwind in the form of the coronavirus, irrespective of the suitability for extra investment assistance to companies (Xiang et al. 2021). They are directed on abating the spillover of headwinds that emanate from the investment sector and on avoiding those headwinds from coming to fruition in the first place, i.e., the deposit insurance, lender of the last resort, and the Basel III bank capital regulation. Throughout previous crises that the financial sector was the epicenter, policy formulators would come in and determine the financial mediators or borrowers in trouble, saving the entire system from falling (Wu et al. 2022). When policy formulators tackled the financial sector's critical issue, banks revitalized credit lending to the real sector and economic activity (Krüger and Meyer 2021).

The coronavirus is different because, around the world, its actual effect, i.e., loss of life, plus economic undertakings, are constantly tracked and examined in two ways different from the past crises. To begin, with a tremendous amount of important index concerning the coronavirus as well as their analysis by the scholarly society in the recognized media outlets are accessible to the financiers on a real-time basis (Mohsin et al. 2019), (Mohsin et al. 2020a), and (Mohsin et al. 2021a). The main headline indexes are anticipated to create significant information distribution and accumulation. The accessibility of information on real-time basis ensures investors evaluate the anticipated future ramifications of economic activity. These front-page stories indexes act as a systematic source of general data and add to the development of the same financier's cost anticipations (Haagh 2020). Next, financiers have the availability of stochastic non-methodical information online (Zhuang et al. 2021), (Li 2020), and (Kong and He 2020).

Nonetheless, this type of information might be consistent and correct and might add to the noise in costs. Francis (2020) record the function of misrepresentation, falsehood, and opinion-based views that lead to information lopsidedness. We contend that the newness of the virus burdens and the complex virus spread might contribute to the misrepresentation by an inexperienced speaker on the subject matter from online, even excluding the mind to peddle falsehood (Yang et al. 2021), (He et al. 2020) and (Mohsin et al. 2020b). The high technical ability required to process the know-how nature miniature of the virus might lead to misrepresentation. This misrepresentation is then spread sub-consciously to several others throughout papers, blogs, and social platform posts. The non-methodical information from 
online, as a result, might add to doubts and variances in anticipation of market actors, resulting in vulnerable markets (Deardorff et al. 2020), (Caballero-Morales 2021), and (de España 2020). These twofold causal factors beyond the information movement attain different impacts on the costs and vulnerability of financial markets. The organized communication movement should dim the volatility and add to the revitalization process by creating a sameness of anticipations. Contrarily, the non-methodical parts of the information movement ought to heighten the vulnerability within the financial markets and lead to a communication path that is not effective.

\section{Data and methodology}

\subsection{Econometric strategy}

Monetary policy can act an important role in decreasing the impacts of the coronavirus. Nevertheless, the kind of implementation of policy monetary might differ crosswise economies regarding their economic circumstance throughout the current pandemic. Hazakis (2021) contended that it might be financial movements. But, developing countries can implement the integration of inflation controlling and macroprudential instruments plus financial movements (Vidya and Prabheesh 2020). Considering this policy model eases financial steadiness, the developing countries can implement similar integration of policies to react to the interruptions occasioned by the coronavirus (Batool et al. 2021). As the pandemic is linked to reduced inflation in the industrialized economies, growth monetary policy could ease greater economic expansion and more significant financing. Therefore, implementing monetary policy in developed nations impacts developing the countries' economic policy strategies (Anh and Gan 2020).

Further, the part play of trade and investment coupling brings headwinds spread and causes the anxiety of financial pandemic. Babatope Taiwo et al. (2021). As a result, the efficacy of the domestic monetary policy will be reliant on headwinds knock-on effects from the industrialized countries. For this reason, the implementation of monetary policy efficiency.

$$
V(w, a)=E(U(s) w)+a=\int U(Y, Z) \pi(d z / w)+a .
$$

In Eq. (1) $V(w, a)$ is shown that social welfare given the indication or signs as well as various policy correlated differences recognized as $a$ and $\pi(d z / w)$, and supply of final health state's conditional on the signal $w$, GHE depicts the dependent parameter, and represents the health spending, a percentage of gross domestic product, gross domestic purchasing power parity is the gross domestic product per head, $\alpha$ depict the intercept purchasing power parity. Throughout the first levels, the government determines the half expenditures of monies based on maximizing expected utility stated at the initial stage; the government decides the percentage payments 
of investing by taking a complete opportunity of predicted utility (Bordo and Levy 2021). By integrating the phase-out of the initial stage, recognizing the signs from the coronavirus's trend within the country (Wei and Han 2021). Thus, from max ( $V$ $(w, a))$, we obtain $(3) h^{*}=h(w, a)$ where $h^{*}$ shows the total public health spending. The Central Banks uses a Taylor rule subject to a direct zero lower bound in Eq. (2),

$$
\frac{1}{Q_{i}}=m\left\{1,\left(\frac{\pi}{\pi}\right)^{\emptyset \pi}\right\}\left(\frac{P_{t}^{a}}{P_{t-1}^{a}}\right)^{\emptyset a}\left(\frac{1-N_{t}^{n}-N_{t}^{n}}{\dddot{U}}\right)^{\emptyset u} .
$$

The interest rate thus responds to differences in variations in the costs sector plus the services sector and moves away from the unemployment rates from its constant stage $\dddot{U}$. The financial regulators attain movement correlated to non-service spending Gt, unemployment cover $U_{i t}$, and debt repayments $\frac{B_{t-1}^{g}}{\pi_{t}}$. Its inflows are labor income/payroll taxes $\tau_{t}^{1}\left(N_{t}^{a}+N_{t}^{n}\right)$, capital income/profit taxes $\tau_{t}^{1} \mathrm{P}_{t}^{n}$, debt issuance $B_{t}^{g}$ , and lump-sum taxes $T_{t}^{S}$. Further, the fiscal authority can spend in varied types of expenditure. Indeed, the spending of different kinds is regarded as Nt (McKibbin and Vines 2020). The public budget constraint in Eq. 3 is.

$$
G_{t}+\frac{B_{t-1}^{g}}{\pi_{t}}+U_{i t}\left(1-N_{t}^{a}-N_{t}^{n}\right)+\mathbb{N}_{t}=\tau_{t}^{1}\left(N_{t}^{a}+N_{t}^{n}\right)+\tau_{t}^{1} \mathrm{P}_{t}^{n}+B_{t}^{g}+T_{t}^{S}
$$

And

$$
T_{t}^{S}=\left[\frac{B_{t-1}^{g}}{\overline{B^{g}}}\right]^{\phi \tau}-1
$$

where $\phi \tau$ depicts the pace of modification in Eq. 4. A reduced figure implies there is no ample funding to expend now relative to investment obligations. As a result of the fact that markets have symmetric information in the markers, and borrowers have restrains to borrow (DORUK et al. 2021). These parts of $f \mathbb{N}_{t}$ (Eq. 5) are: (i) Free cash handout to al agents within the economy, $T_{t}^{b}$, and (ii) payments to the service companies are equal to their income levels, $T_{t}^{a} W_{t} J_{t}^{n}$. Thus,

$$
\mathbb{N}_{t}=T_{t}^{b}+T_{t}^{a} W_{t} J_{t}^{n}
$$

In addition, the scholars believe that the government can completely change the current fiscal instruments. (iii) An expansion in non-service spending Gt, (iv) An expansion in unemployment cover handouts is $U_{i t}$, and (v) a cut in the payroll tax is $\tau_{t}^{1}$. They form the five key flexible fiscal instruments that will be the principal analysis quantitatively within the next sections. (Akrofi and Antwi 2020).

$$
=\alpha+\beta 1 X_{1}+\beta 2 X_{2}+\cdots+\beta n X_{n}+\varepsilon_{j, t} .
$$


Government Spending $_{j, t}=\alpha+\beta 1 G D P C o n s u m p t i o n$ Investment $_{j, t}$

$$
\begin{aligned}
& +\beta 2 \text { Governmnet Revenue }_{j, t} \\
& +\beta 3 \text { Interest rate }_{j, t}+\beta 4 \text { Public Aid }_{j, t} \\
& +\beta 4 \text { Unemployement }_{j, t}+\varepsilon_{j, t}
\end{aligned}
$$

$$
\begin{aligned}
\text { CRSTE }_{j, t}= & \alpha+\beta \text { 1 Government Spending }_{j, t}+\beta 2 \text { Government revenue }_{j, t} \\
& +\beta 3 \text { GDP Consumption Investment }_{j, t}+\beta 3 \text { Interest rate }_{j, t} \\
& +\beta 4 \text { Public Aid }_{j, t}+\beta 5 \text { Unemployement }_{j, t}+\varepsilon_{j, t}
\end{aligned}
$$

Within the models (4)-(6), here $c$ is the intercept term, $a$; $b$ are approximated coefficients of the independent parameters, correspondingly, $d 1 ; d 2 ; d 3 ; d 4$ are the examined coefficients controlling parameters, $x$ depicts the random term the, $j$ depicts to the $j$ th enterprises $s$, and $t$ explains the $t$ th year during the duration of the study.

\subsection{Data collection and sources}

Here, financing in listed companies in Chinese RE energy on the Shanghai and Shenzhen Stock exchanges study the government policy incentives and take holidays. To ensure sample time series could maintain their temporal steadiness and correctness, this research delves into the subsequent steps: To begin with, this analysis comprises all companies in the clean energy sector from 2000 to 2018 for the examination. Thus, in China, some strong presumptions are made to advance a theoretical equation to an experiential equation. The actual gross domestic product productivity, inflation, and interest rate data are derived from the International monetary fund database. The total yearly financing and self-financing data are obtained from the China Bureau of Statistics and interpolated for quarterly values. EPS data platform. Also, the following sources have been used as data sources, Ministry of Industry and Information Technology, Evaluation Report on the Development Level of the Integration of "Informatization and Industrialization," China high-tech industry statistical yearbook, and local government websites.

\subsection{Empirical explanation of study constructs}

The findings depict the mean figure of absolute, technological, and scaled efficiency. A complete output estimation and evaluation of capability plus the application of renewable energy enterprises are vital for decision making. If clean energy companies are close to the output boundary, gross spending productivity would be near. From 2010 to 2017, the volume of spending in green energy firms increased and finally reduced to the stage of being the same amount to their total financing in 2010, which is nearly 100 percent. Regarding renewable energy technology firms, only implementations, management standards, and technological capabilities are 
Table 1 Econometric Analysis

\begin{tabular}{llllll}
\hline & $(1)$ & $(2)$ & $(3)$ & $(4)$ & $(5)$ \\
\hline Government spending & 0.7684 & 1.7662 & 1.5547 & 0.2547 & 0.8645 \\
Government revenue & 1.5637 & 0.8745 & 0.5546 & 1.5784 & 1.5524 \\
GDP consumption investment & 0.4428 & 1.5438 & 1.7652 & 0.7932 & 0.7543 \\
Interest rate & 0.5579 & 0.8799 & 0.7654 & 0.4651 & 0 \\
Public aid & 0.6642 & 1.8794 & 1.8792 & -0.3541 & 0.5642 \\
Unemployment & 0.5748 & 1.8765 & 1.3451 & 0.5641 & 0.7654 \\
\hline
\end{tabular}

Table 2 Fiscal policy analysis

\begin{tabular}{llllrl}
\hline & $(1)$ & $(2)$ & $(3)$ & \multicolumn{1}{l}{$(4)$} & \multicolumn{1}{l}{$(5)$} \\
\hline Government spending & 0.5547 & 0.9987 & 0.5634 & 0.8745 & 1.7458 \\
Government revenue & 0.6824 & 1.7658 & 1.5624 & 0.5874 & 1.5466 \\
GDP consumption investment & 1.4521 & 1.7745 & 1.7965 & 0.7784 & 0.5478 \\
Interest rate & 0.7865 & 0.8721 & 0.7985 & 0.6874 & 0.8759 \\
Public aid & 1.9768 & 1.6741 & 1.4489 & -0.5632 & 0.5632 \\
Unemployment & 1.7456 & 1.8745 & 1.9874 & 0.5478 & 0.8523 \\
\hline
\end{tabular}

important, and aggregate installed capacity additions for renewable energy will attain complete productivity competence. Clean energy technical implementations are only more significant than 9th-1000 s of 1 percent, depicting that renewable energy approaches are extra technologically complex than the selected negative emissions technologies. Efficient upscaling implies comprehending and proving solutions to the subsequent questions. At what magnitude do green energy firms attain the status of extra efficiency? The scale utility ought to become sustainable. Nonetheless, it might grow or reduce to equal supply and demand.

\section{Results and discussion}

\subsection{Econometric estimation}

Table 1 findings depicted that the median magnitude mirrored an increasing trend in green energy firms around 0.53 percent to 0.98 percent with the previous years. Further, RE expenditure extra in 2014 is their strategy for energy conservation. Generally, the Chinese power supply has even become less consistent. Broad speaking, energy expenditure depicts a greater scope. Nonetheless, green enterprises will try to limit the cumulative expenditure spectrum. The tax cut rate was reduced from 18 to 12 percent. The real gross domestic product increased by 0.22 percent, which shows the tariff reduction policy was encouraged by country-wide economic vast increment. 
Further, people's income and total expenditure expanded from 1.79 percent to 1.03 percent. The number of people living in area sources of sustenance improved. Expanding the populace's expenditure interacted with the general standard requirements, thus boosting solid economic developments.

Table 2 shows that foreign trade and investment expanded to 1.41 percent and 0.21 percent, respectively, signifying the tariff reduction had reduced firms' expenditures and goods figures. It improved the affordability of goods traded in a foreign land. So, action is planned to calm the outlooks and encourage the investment requirements of marketplace bodies. To begin with, the multiplier in regular times is less than around the pandemic period. Next, the grouping of multipliers for jobs changes at standard times. In the event of a shock, as presented in the subsequent findings, universal income overtakes tax reductions.

Tables 2 and 3 show that to examine the consistency of the equation and create a point that it generates plausible results. We reestimated the fiscal multiplier for the same policy tools without the coronavirus shock. Thus, we utilize the estimated equation to approximate the fiscal multiplier in standard time where external interruptions are present other than the stimulus packages and the reference year excluding stimulus package within the economy when it is at its steady state. The gross domestic product and employment of nations expenditure are between 0.81 and 0.85 percent, respectively.

Overall, in Table 4, applying the Hausman's analysis method, we initially determine whether financing implementation, public incentives. Consequently, the direct reaction of the gross domestic product in Japan expanded to 0.27 percent relative to almost no variations in the USA and the EU in quarter eight. Further, the strange reaction of every nation, the reaction figures of different countries expanded initially and finally reduced, and steady afterward of quarter eight. The reaction

Table 3 Regression analysis

\begin{tabular}{lllllll}
\hline & & & $(3)$ & $(4)$ & $(5)$ & $(6)$ \\
\hline Government Spending & $-19.97^{* * *}$ & $-33.33 * * *$ & $-33.54 * * *$ & $-19.31 * * *$ & $-31.31 * * *$ & $-33.33 * * *$ \\
& $(-5.09)$ & $(-5.54)$ & $(-5.34)$ & $(-5.01)$ & $(-4.53)$ & $(-5.54)$ \\
GDP Consumption & $0.57 * * *$ & $0.39 * *$ & $-0.39 * * *$ & $-0.90^{* * *}$ & $0.57 * * *$ & $0.39 * *$ \\
Investment & -3.79 & -1.99 & $(-4.31)$ & $(-5.35)$ & -3.79 & -1.99 \\
Government Revenue & 337.51 & $547.31^{* *}$ & $534.01 *$ & $1137.33 * *$ & 337.51 & $547.31 * *$ \\
& -0.79 & -1.79 & -3.55 & -3.53 & -0.79 & -1.79 \\
Interest rate & $0.19 * * *$ & $0.31 * * *$ & $0.43 * * *$ & $0.43 * * *$ & $0.19 * * *$ & $0.31 * * *$ \\
Public Aid & -4.41 & -3.3 & -5.33 & -5.4 & -4.41 & -3.3 \\
Unemployment & -0.31 & $-0.55^{* * *}$ & -0.31 & -0.35 & -0.31 & $-0.55 * * *$ \\
& $(-3.14)$ & $(-4.31)$ & $(-0.59)$ & $(-0.57)$ & $(-3.14)$ & $(-4.31)$ \\
R-squared & $-0.53 * * *$ & & $-0.50 * * *$ & & $-0.53 * * *$ & \\
Exchange Rate Regime & No & No & Yes & No & Yes & No \\
\hline
\end{tabular}


Table 4 Fiscal policy analysis

\begin{tabular}{|c|c|c|c|c|c|c|}
\hline & (1) & (2) & (3) & (4) & (5) & (6) \\
\hline Government Spending & $\begin{array}{l}-18.87 * * * \\
(-5.08)\end{array}$ & $\begin{array}{l}-22.22 * * * \\
(-5.54) \\
0.57 * * *\end{array}$ & $\begin{array}{l}-22.54 * * * \\
(-5.24) \\
0.28 * *\end{array}$ & $\begin{array}{l}-15.42^{* * *} \\
(-2.75)\end{array}$ & $\begin{array}{l}-18.21 * * * \\
(-5.01) \\
-0.28 * * *\end{array}$ & $\begin{array}{l}-21.21 * * * \\
(-4.52) \\
-0.80 * * *\end{array}$ \\
\hline $\begin{array}{l}\text { GDP Consumption } \\
\text { Investment }\end{array}$ & & $\begin{array}{l}-2.77 \\
227.51\end{array}$ & $\begin{array}{l}-1.77 \\
547.21 * *\end{array}$ & & $\begin{array}{l}(-4.21) \\
524.01 *\end{array}$ & $\begin{array}{l}(-5.25) \\
1127.22 * *\end{array}$ \\
\hline Government Revenue & & $\begin{array}{l}-0.78 \\
0.18^{* * *}\end{array}$ & $\begin{array}{l}-1.78 \\
0.21 * * *\end{array}$ & & $\begin{array}{l}-2.55 \\
0.42^{* * *}\end{array}$ & $\begin{array}{l}-2.52 \\
0.42^{* * *}\end{array}$ \\
\hline Interest rate & & $\begin{array}{l}-4.41 \\
-0.21\end{array}$ & $\begin{array}{l}-2.2 \\
-0.55^{* * *}\end{array}$ & & $\begin{array}{l}-5.22 \\
-0.21\end{array}$ & $\begin{array}{l}-5.4 \\
-0.25\end{array}$ \\
\hline Public Aid & & $(-2.14)$ & $\begin{array}{l}(-4.21) \\
-0.52 * * *\end{array}$ & & $(-0.57)$ & $\begin{array}{l}(-0.57) \\
-0.50^{* * *}\end{array}$ \\
\hline Unemployment & & & $\begin{array}{l}(-4.57) \\
0.07 * * *\end{array}$ & & & $\begin{array}{l}(-5.87) \\
-0.05\end{array}$ \\
\hline R-squared & 0.05 & 0.12 & 0.21 & 0.18 & 0.19 & 0.18 \\
\hline Exchange Rate Regime & $\mathrm{NO}$ & $\mathrm{NO}$ & YES & $\mathrm{NO}$ & $\mathrm{NO}$ & YES \\
\hline
\end{tabular}

All regressions include regional and version dummies. Robust $t$ statistics are in parentheses.

figures in the USA, the European Union, and Jan are 0.141 percent plus 0.72 percent correspondingly.

\subsection{Government spending during COVID-19}

Utilizing green energy firm-level data (Table 5), Table 3 depicts the experimental analysis of the impacts of subsidies plus tax discount on general spending performance, directly associated with cumulative financing efficiency at the ten percent confidence level. This differentiates the effect of the pandemic headwinds, which looks probable to be U-shaped productivity pathways that stay at the base at one quarter and continue steadily in the nine quarters. Indeed, the grot to 6.7 gross domestic product declines to 9.9 percent in quarter two, recovers, and increases to 6.7 percent plus 5.9 percent in the next horizons in China.

The spending of Ricardians is less reactive to the coronavirus than non-Ricardian due to house owners having monetary and physical assets whose profits grow as a result of rich asset valuation throughout the phase of the pandemic. The wealth impact via the costs pathway looks to have reduced the fall in the spending of Ricardians. (Faria-e-Castro 2021) demonstrates that the asset costs pathways are one of the casual factors of actual productivity in Turkey. The growth monetary policy in the form of interest reductions, liquidity payment through outright bond buys, limiting reserve requirement ratio, and collateral access have expanded asset costs, and substantial liquidity looks likely to have formed the economic decisions of the stakeholders through wealth impacts. 


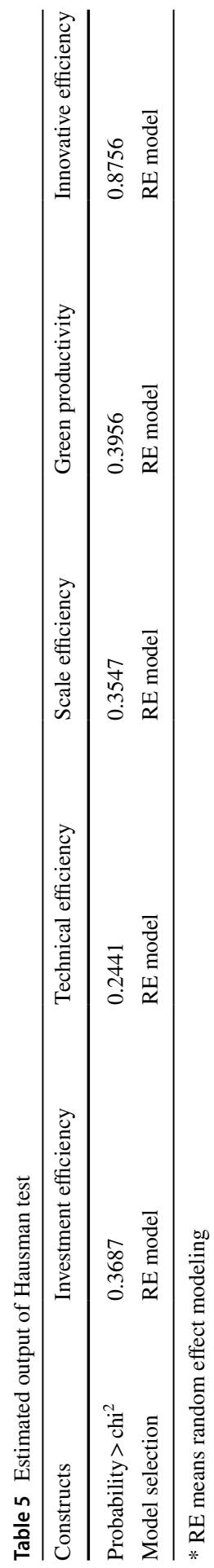


The instant gross domestic product reaction of spillover impacts. Nevertheless, the immediate energy reaction spillover impacts in different nations are minute, excluding Australia, 0.24 percent. For the extended term regarding the gross domestic product reaction to the spillover impacts, the reaction figure of Korea steady at around 0.16 percent plus 0.48 percent, ultimately. The UK attains the most significant decline; the figure has declined to 0.35 percent to nearly zero percent. Put differently; this direct reaction seems to be no-significant at quarter four after the headwinds. Contrarily, China has a minor decline, alongside the reaction figure declining to 0.28 percent to 0.15 percent. Correspondingly, the extended-term reaction is estimably steady at 0.47 percent, 0.85 percent. Nonetheless, Australia's reaction figure is extremely non-significant. (Büyükbaşaran et al. 2020). The tax discounts variable attains a coefficient of 0.0149 percent, and rebate taxation derived by RE enterprises is directly correlated to cumulative financing efficiency at the ten percent confidence level.

Concerning the extended parameter (Table 6), gross domestic product reaction $n$ attained a height of 0.5 percent in quarter two, as well as the extended run steadied at 0.37 percent after quarter twelve. The long-term gross domestic product reaction figure for the spillover impacts began to fall after quarter zero regarding the proposed countries. This is contrary to the long-run gross domestic product reaction of significant trading partners in high-income countries. Additionally, Table 7 shows the long-term gross domestic product reactions of continue to be 0.33 percent, and 0.29 percent, respectively. Furthermore, regarding the extended period of reaction to the diffusion impacts of economic expansion in China, New Zealand, Saudi Arabia, Sweden, and Switzerland equally obtained a direct diffusion impacts of Chinese economic growth, alongside a long-term reaction's figures of nearly 0.29 percent, 0.59 percent, plus 0.33 percent, correspondingly. Nonetheless, correspondingly, the

Table 6 Regression analysis

\begin{tabular}{|c|c|c|c|c|c|c|}
\hline & (1) & (2) & (3) & (4) & (5) & (6) \\
\hline Government Spending & $\begin{array}{l}-17.77 * * * \\
(-6.05)\end{array}$ & $\begin{array}{l}-33.32 * * * \\
(-6.56) \\
0.67 * * *\end{array}$ & $\begin{array}{l}-23.66 * * * \\
(-6.26) \\
0.35 * *\end{array}$ & $\begin{array}{l}-15.63^{* * * *} \\
(-3.76)\end{array}$ & $\begin{array}{l}-17.21 * * * \\
(-5.01) \\
-0.35 * * *\end{array}$ & $\begin{array}{l}-31.21 * * * \\
(-6.63) \\
-0.50 * * *\end{array}$ \\
\hline $\begin{array}{l}\text { GDP Consumption } \\
\text { Investment }\end{array}$ & & $\begin{array}{l}-3.75 \\
327.61\end{array}$ & $\begin{array}{l}-1.55 \\
667.31 * *\end{array}$ & & $\begin{array}{l}(-6.21) \\
636.01 *\end{array}$ & $\begin{array}{l}(-5.36) \\
1127.33 * *\end{array}$ \\
\hline Government Revenue & & $\begin{array}{l}-0.75 \\
0.15^{* * * *}\end{array}$ & $\begin{array}{l}-1.75 \\
0.31 * * *\end{array}$ & & $\begin{array}{l}-2.56 \\
0.62 * * *\end{array}$ & $\begin{array}{l}-3.52 \\
0.63 * * *\end{array}$ \\
\hline Interest rate & & $\begin{array}{l}-6.61 \\
-0.31\end{array}$ & $\begin{array}{l}-3.3 \\
-0.65 * * *\end{array}$ & & $\begin{array}{l}-6.23 \\
-0.21\end{array}$ & $\begin{array}{l}-5.6 \\
-0.26\end{array}$ \\
\hline Public Aid & & $(-2.16)$ & $\begin{array}{l}(-6.21) \\
-0.63 * * *\end{array}$ & & $(-0.55)$ & $\begin{array}{l}(-0.67) \\
-0.60 * * *\end{array}$ \\
\hline Unemployment & & & $\begin{array}{l}(-6.55) \\
0.07 * * *\end{array}$ & & & $\begin{array}{l}(-5.57) \\
-0.05\end{array}$ \\
\hline R-squared & 0.06 & 0.12 & 0.31 & 0.05 & 0.21 & 0.15 \\
\hline Exchange Rate Regime & NO & NO & YES & NO & NO & YES \\
\hline
\end{tabular}

All regressions include regional and version dummies. Robust $t$ statistics are in parentheses. 
Table 7 Regression Analysis

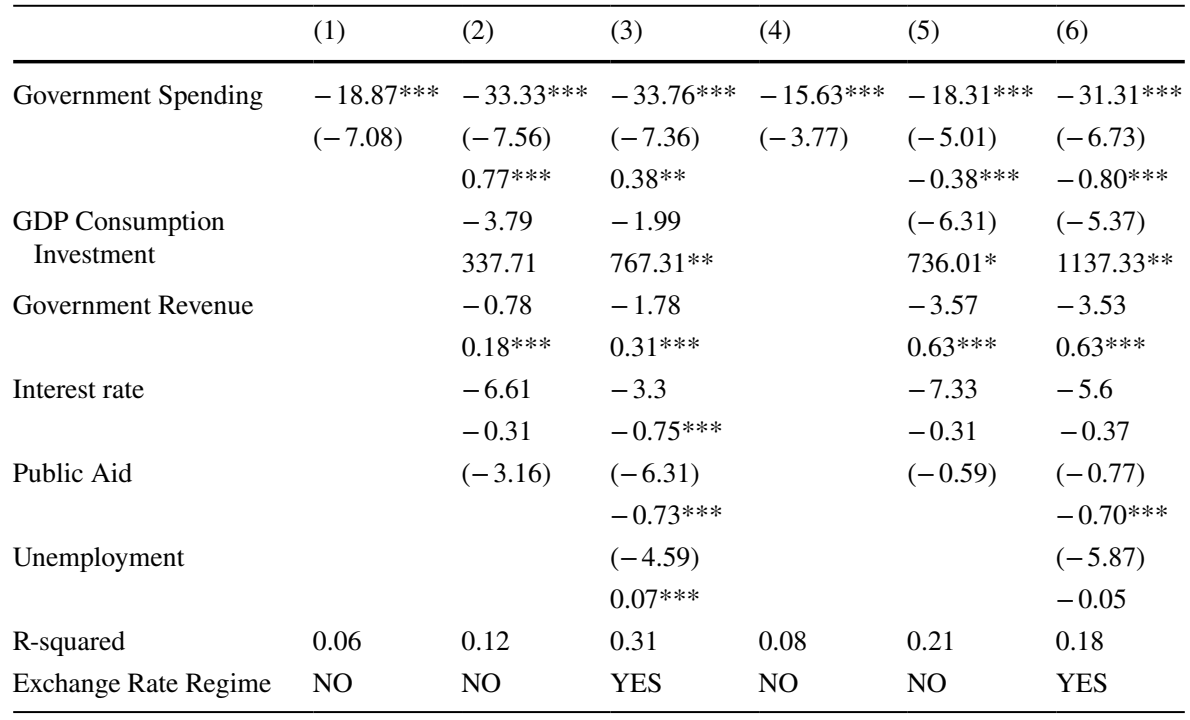

All regressions include regional and version dummies. Robust $t$ statistics are in parentheses.

Table 8 Regression Analysis

\begin{tabular}{|c|c|c|c|c|c|c|}
\hline & (1) & (2) & (3) & (4) & $(5)$ & (6) \\
\hline \multirow[t]{3}{*}{ Government Spending } & $-17.77 * * *$ & $-44.42 * * *$ & $-24.54 * * *$ & $-15.44 * * *$ & $-17.21 * * *$ & $-41.21 * * *$ \\
\hline & $(-5.07)$ & $(-5.54)$ & $(-5.24)$ & $(-4.75)$ & $(-5.01)$ & $(-4.54)$ \\
\hline & & $0.57 * * *$ & $0.47 * *$ & & $-0.47 * * *$ & $-0.70 * * *$ \\
\hline \multirow{2}{*}{$\begin{array}{l}\text { GDP Consumption } \\
\text { Investment }\end{array}$} & & -4.79 & -1.99 & & $(-4.21)$ & $(-5.45)$ \\
\hline & & 427.51 & $547.41 * *$ & & $544.01 *$ & $1127.44 * *$ \\
\hline \multirow[t]{2}{*}{ Government Revenue } & & -0.77 & -1.77 & & -2.55 & -4.52 \\
\hline & & $0.17 * * *$ & $0.41 * * *$ & & $0.42 * * *$ & $0.44 * * *$ \\
\hline \multirow[t]{2}{*}{ Interest rate } & & -4.41 & -4.4 & & -5.24 & -5.4 \\
\hline & & -0.41 & $-0.55 * * *$ & & -0.21 & -0.25 \\
\hline \multirow[t]{2}{*}{ Public Aid } & & $(-2.14)$ & $(-4.21)$ & & $(-0.59)$ & $(-0.57)$ \\
\hline & & & $-0.54 * * *$ & & & $-0.50 * * *$ \\
\hline \multirow[t]{2}{*}{ Unemployment } & & & $(-4.59)$ & & & $(-5.77)$ \\
\hline & & & $0.07 * * *$ & & & -0.05 \\
\hline$R^{2}$ & 0.05 & 0.22 & 0.41 & 0.07 & 0.19 & 0.17 \\
\hline Exchange Rate Regime & NO & NO & YES & NO & NO & YES \\
\hline
\end{tabular}

All regressions include regional and version dummies. 
long-term reaction values of negative 0.02 percent, negative 0.33 percent, and negative 0.01 percent.

In contrast, the instant response of numbers of Norway and Sweden were negative 0.26 percent plus 0.78 percent, individually. The rapid reactions of different nations were non-significant.

To begin with, in Table 8, from the viewpoint of rapid reactions, Brazil and Indonesia give meaningful and statistically explicit reactions. In quarter zero, the reaction figures of gross domestic product are 0.34 percent, plus 0.14 percent correspondingly. Contrarily, the sudden reaction figure of energy is not specific. Next, in quarter one, Indonesia's direct gross domestic product reaction expanded and attained the height of 0.55 percent, nonetheless reduced throughout a similar period. Other than that, the energy reaction numbers of the two countries indicated a growing trajectory in quarter zero-two. Next, from the viewpoint of extended long-term reaction, the gross domestic product and energy reaction number of Indonesia stayed at nearly 0.28 percent, plus 0.24 percent afterward quarter four, individually, which are meaningful and direct. Nevertheless, China's extended-term gross domestic product reaction is not meaningful; only a tremendously minute direct reaction was sustained. The extended-term energy reaction in Brazil is 0.61 percent.

Likewise, tax cuts, perhaps exemptions on spending and salaries, looks to have assumed a U-shaped pathway in lump-sum earrings that based away at the fifth quarter. In all honesty, the lump-sum tax earnings in the US parameters via 2020 stayed steady relative to 2019. Nonetheless, earnings tax plunged steeply to 21 percent. Regarding a quarter by quarter comparison, taxes earnings fell by 20 percent in quarter two, 2020 next to a 44 percent increase in quarter three due to the most negligible reference impact and elimination of constraints, 4 percent and 23 percent reductions in the ensuing years, individually. The most significant cause of this fall is the cuts in earnings and particular spending tax. Wirth the 5th quarter, the lump-tax earnings would grow fundamentally to contain an increasing government spending as suggested by Ricardian equivalence. The proportion of government's end energy spending in gross domestic product stays steady from 2019 to 2020, nearly 15 percent.

Nonetheless, the government spending has increased throughout the coronavirus phase with social aid, which re equal to 1.1 percent of gross domestic product, plus equity disbursement into the public financial system, 0.4 percent of gross domestic product. Social aid entails disbursements to citizens who have financial difficulties. The labor demand falls steeply and based out into quarter two. Nonetheless, it seems to be recovering at a slow pace. The joblessness rate has increased to 13.4 percent in the quarter to, next to a moderate fall in 12.5 percent as well as 12.6 percent in the subsequent phases. The findings reveal extra severe impacts on-demand labor. Contrarily, the fall in earnings tax to 21 percent corroborates the analysis and a job decline. Nonetheless, country-wide restrains on employee sacking, and short-term programs reduced probable extra increases in the unemployment rates, which implies an estimation inconsistency among underemployed and those in active employment.

With the relaxing of monetary policy circumstances, defaults in payback likelihood fell rapidly and regained in the second phase, in line with the increase in interest rates. The proportion of bad loans in the cumulative loans fell to 4.46 percent in quarter two, next to 4.06 percent as well as 4.08 percent in the following quarter. 
Table 9 Sensitivity analysis

\begin{tabular}{llll}
\hline & $(1)$ & $(2)$ & $(3)$ \\
\hline Government spending & $-20.43^{* * *}$ & $-28.46^{* * *}$ & $-32.77^{* * *}$ \\
GDP consumption investment & $(-4.11)$ & $(-5.23)$ & $(-5.67)$ \\
& $0.56^{* * *}$ & $0.41^{* *}$ & $-0.41^{* * *}$ \\
Government revenue & -2.81 & -1.98 & $(-4.45)$ \\
& 322.77 & $533.69 * *$ & $493.72^{*}$ \\
Interest rate & -0.65 & -1.32 & -3.87 \\
& $0.21^{* * *}$ & $0.22^{* * *}$ & $0.382^{* * *}$ \\
Public aid & -2.87 & -3.21 & -5.76 \\
& -0.21 & $-0.53 * * *$ & -0.32 \\
Unemployment & $(-3.63)$ & $(-4.22)$ & $(-0.66)$ \\
$R^{2}$ & $-0.43 * * *$ & & 0.32 \\
Exchange Rate Regime & & $(-4.598)$ & Yes \\
\hline
\end{tabular}

Nonetheless, the quality of bank assets matters due to the metric that can be approximated due to a steep credit expansion energized through a Credit guarantee.

\subsection{Robustness analysis}

Table 9 provides the sensitivity analysis. These are economic policy instruments. Nevertheless, it is differently attractive for cash handout firms: The work multiplier is too non-significant in average years, i.e., 0.32 against 2.51 within the pandemic era, and the gross domestic product multiplier are not enticing, negative 0.11 as against 0.45 . Also, cash assistance to enterprises is hence not the ideal thing in prosperous times. Nonetheless, it presents soothing effects on employment in the likelihood of an external interruption such as the coronavirus.

The USA, the EU, plus Japan, are China's most trading top three trading partners. First, regarding the instant gross domestic product reaction to the spiller over impacts of economic expansion in the USA, China, the EU, and Japan reacted to the direct headwinds in China to 0.32 percent, 0.53 percent, as well as 0.66 percent in quarter zero, correspondingly. Additionally, the energy consumption reacted to 0.07 percent, 0.15 percent, plus 0.28 percent, correspondingly; Between the study nations, Japan's instant reaction was the biggest. Next, we detect that the reaction figure of the gross domestic product is reducing; nonetheless, reaction figure of energy consumption is growing afterward quarter zero. Peculiar to the awful domestic reaction of every country, the reaction figure of the USA is 0.12 percent is more significant than the EU union of 0.02 percent afterward the quarter four. 


\section{Conclusion and policy implications}

Actions taken to contain the coronavirus have caused an economic recession in recent human memory and have upended fiscal and monetary policies of the nation, not to take about accentuating the energy challenges faced by countries in 2020. By courtesy of efficient control measures, China has been able to build back better from the pandemic than any other nation. This research piece seeks to evaluate the effect of gross domestic product expansion in China's own economy and energy of different economies to analyze the spillover impacts of Chinese economic recovery among other nations. To begin, a non-static in China's economic recovery and findings affirm that the big Chinese economies of scale will perform a significant part in revamping the world's economy. That is, China is indispensable in the build-back efforts of the world. More so, this spillover impact is progressive, nonetheless not static.

Similarly, irrespective of the earning levels, other nations' instant gross domestic product reaction to China's spillover impacts is the most felt and then slowing plunges. Beyond quarter six, it balances at a particular figure and results in a persistent and fragile extended-term reaction from the pandemic. Thus, this casual impact remains robust into the first two quarters after the headwinds and eventually becomes fragile. Ultimately, energy consumption will sustain a steady long-run direct reaction.

Furthermore, the findings from the heterogeneous evaluation show that the spillover impact of Chinese economic build-back better programs are varied to nations with various earrings levels. Regarding the economic reaction to the pandemic viewpoint, the heterogeneity is revealed in twofold spillover impacts: the initial part is the reaction pace. The next pace is the distribution pathways. Generally, it is clear that the curves are grouped into two parts based on the reaction variation trajectory. Quarter six is the inflection point, and the curves close to quarter six depict full, varied information. More precisely, over 80 percent of nations had the biggest reaction value in quarter zero prior to quarter six. This implies that When China's economy changes, different nations will be confronted with a bigger instantaneous effect. Next, as the quarter expands, the spillover impact starts to reduce as well as it is associated with tiny variations. Put differently, the direct spillover impact on Chinese economic expansion is only felt in a meaningful part in a reduced timeframe. After quarter six, the extended long-term reaction of an extra 85 percent of the nations.

The study finds that such optionality is an essential aspect to revivability. Hence, policies that encourage such structural variation should be a vital part of programs developed to result in the economic build back better of the sub-region. This is especially vital because the findings depict different grouping of the well and poorly functioning regions, leading to sociopolitical upheavals owing to the variances in the economic wealth of regions within a nation. Considering the present scholarly works on the pandemic highlight that its gravest effects are on savings and the vulnerable, people with low earnings are not likely to vary attitude in the form of social distancing. Thus, this analysis gives proof of provincial disparities to imply further obstacles for policy formulators to contain the virus.

The analysis of the equation highlights the chosen macroeconomics parameters reaction to the extra fiscal measure of the employee resulting from a decline in mean 
salary per worker due to the coronavirus. Regarding the monetary actions, reductions in interest and reserves need ratios to seem not to have a direct explicit effect on productivity. Between the monetary policy actions, only the cuts in collateral loan rate appear to explicitly abate an adverse effect of the pandemic productivity and spending.

This study depicts that explicit fiscal actions are extra effective in abating adverse effects of the pandemic in Turkey, whereas relaxing monetary policy has anticipated side impacts. It appears that containment monetary actions were taken against the pandemic further increased cost caused inflationary stresses that have been initially coming from the used capacity, growing the commodity costs and exchanges rates increases owing to the pandemic. Thus, this analysis explains that the direct fiscal policy actions that will aid the most vulnerable aspects of the economy could be more efficient in fighting the adverse effects of the pandemic in the open and a minute economy. An extra focused and integrated policy mix that comprises additional explicit fiscal tools and farsighted monetary policy that is extra suitable to aid productivity and consumption whereas eschewing unwanted side impacts in the form of inflation that might enhance more an encompassing movable investment ecology.

\section{References}

Akrofi MMC, Antwi SH (2020) COVID-19 energy sector responses in Africa: A review of preliminary government interventions. Energy Res Soc Sci 68:101681

Anh DLT, Gan C (2020) The impact of the COVID-19 lockdown on stock market performance: evidence from Vietnam. J Econ Stud. https://doi.org/10.1108/JES-06-2020-0312

Azad NF, Serletis A, Xu L (2021) Covid-19 and monetary-fiscal policy interactions in Canada. Q Rev Econ Financ. https://doi.org/10.1016/j.qref.2021.06.009

BabatopeTaiwo I, OlatunjiOlaoye C, Adekola Dada R (2021) The roles of SMEs on the sustainable economy growth after Covid-19 pandemic in Nigeria. J Bus Theory Pract. https://doi.org/10.22158/jbtp. v9n2p79

Batool M, Ghulam H, Hayat MA et al (2021) How COVID-19 has shaken the sharing economy? An analysis using Google trends data. Econ Res Istraz. https://doi.org/10.1080/1331677X.2020.1863830

Bordo MD, Levy MD (2021) Do enlarged fiscal deficits cause inflation? The historical record. Econ Aff. https://doi.org/10.1111/ecaf.12446

Büyükbaşaran T, Çebi C, Yılmaz E (2020) Interaction of monetary and fiscal policies in Turkey. Cent Bank Rev 20:193-203. https://doi.org/10.1016/j.cbrev.2020.03.001

Caballero-Morales SO (2021) Innovation as recovery strategy for SMEs in emerging economies during the COVID-19 pandemic. Res Int Bus Financ. https://doi.org/10.1016/j.ribaf.2021.101396

Camous A, Claeys G (2020) The evolution of European economic institutions during the COVID-19 crisis. Eur Policy Anal. https://doi.org/10.1002/epa2.1100

Deardorff A, Kim S, Chung C (2020) The global economy after COVID-19. East Asian Econ Rev. https:// doi.org/10.11644/kiep.eaer.2020.24.4.381

Doruk ÖT, Konuk S, Atici R (2021) Short-term working allowance and firm risk in the post-COVID-19 period: novel matching evidence from an emerging market. Financ Res Lett. https://doi.org/10. 1016/j.frl.2021.102021

ElFayoumi K, Hengge M (2021) Capital markets, COVID-19 and policy measures. IMF Work Pap. https://doi.org/10.5089/9781513569413.001

Elyassi H (2021) Economics of the financial crisis: any lessons for the pandemic downturn and beyond? Contemp Econ. https://doi.org/10.5709/ce.1897-9254.438

de España B (2020) Reference macroeconomic scenarios for the Spanish economy after Covid-19. Analytical Articles. Economic Bulletin, Banco de España (2/2020):1-32 
Faria-e-Castro M (2021) Fiscal policy during a pandemic. J Econ Dyn Control. https://doi.org/10.1016/j. jedc. 2021.104088

Francis D (2020) Unemployment and the gendered economy in South Africa after Covid-19. Transform Crit Perspect South Africa. https://doi.org/10.1353/trn.2020.0036

Gao H, Shi D, Zhao B (2021) Does good luck make people overconfident? Evidence from a natural experiment in the stock market. J Corp Financ. https://doi.org/10.1016/j.jcorpfin.2021.101933

Geghamyan S, Pavlickova K (2019) Does the current state of environmental impact assessment in armenia pose a challenge for the future? J Environ Assess Policy Manag. https://doi.org/10.1142/S1464 333219500042

Goldstein I, Koijen RSJ, Mueller HM (2021) COVID-19 and its impact on financial markets and the real economy. Rev Financ Stud. https://doi.org/10.1093/rfs/hhab085

Haagh L (2020) Rethinking democratic theories of justice in the economy after COVID-19. Democr Theory. https://doi.org/10.3167/dt.2020.070214

Hazakis KJ (2021) Is there a way out of the crisis? macroeconomic challenges for greece after the Covid-19 pandemic. Eur Polit Soc. https://doi.org/10.1080/23745118.2021.1895554

He W, Abbas Q, Alharthi M et al (2020) Integration of renewable hydrogen in light-duty vehicle: nexus between energy security and low carbon emission resources. Int J Hydrog Energy. https:// doi.org/10.1016/j.ijhydene.2020.06.177

Heyden KJ, Heyden T (2021) Market reactions to the arrival and containment of COVID-19: an event study. Financ Res Lett. https://doi.org/10.1016/j.frl.2020.101745

Hilbers AM, Sijtsma F, Busscher T, Arts J (2019) Understanding added value in integrated transport planning: exploring the framework of intelligence, design and choice. J Environ Assess Policy Manag. https://doi.org/10.1142/S146433321950011X

Itani R, Azeem M, Mirza N (2020) Arab Spring and COVID-19: Ex post facto examination of the Lebanese banking sector (the contemporary stakeholder analysis). Banks Bank Syst. https://doi. org/10.21511/bbs.15(4).2020.11

Jinjarak Y, Ahmed R, Nair-Desai S et al (2021) Pandemic shocks and fiscal-monetary policies in the Eurozone: COVID-19 dominance during January-June 2020. Oxf Econ Pap. https://doi.org/10. 1093/oep/gpab010

Kong Q, He J (2020) Controlling methods of driving factors in the economic development of coastal areas. J Coast Res. https://doi.org/10.2112/SI103-027.1

Krüger N, Meyer N (2021) Covid-19 pandemic business relief: a comparative study of South Africa and selected European countries. Pol J Manag Stud. https://doi.org/10.17512/pjms.2021.23.2.15

Lang S, Schadner W (2021) The trilemma of expansionary monetary policy in the Euro area during the COVID-19 crisis. Financ Res Lett. https://doi.org/10.1016/j.frl.2021.102048

Lee S, Liao Y, Seo MH, Shin Y (2020) desperate times call for desperate measures: government spending multipliers in hard times. Econ Inq. https://doi.org/10.1111/ecin.12919

Li Y (2020) Mathematical economics analysis of macro debt and economic growth in coastal areas. J Coast Res. https://doi.org/10.2112/SI103-019.1

Masud R (2020) Development of theoretical and methodological support for evaluating the feasibility of strategic measures to ensure the economic sustainability of the country. Technol Audit Prod Reserv. https://doi.org/10.15587/2706-5448.2020.210854

McKibbin W, Vines D (2020) Global macroeconomic cooperation in response to the COVID-19 pandemic: a roadmap for the G20 and the IMF. Oxf Rev Econ Policy. https://doi.org/10.1093/oxrep/ graa032

Mitha S (2020) UK covid-19 diary: policy and impacts. Natl Tax J. https://doi.org/10.17310/ntj. 2020.3.10

Mohsin M, Rasheed AK, Sun H et al (2019) Developing low carbon economies: an aggregated composite index based on carbon emissions. Sustain Energy Technol Assess. https://doi.org/10. 1016/j.seta.2019.08.003

Mohsin M, Nurunnabi M, Zhang J et al (2020a) The evaluation of efficiency and value addition of IFRS endorsement towards earnings timeliness disclosure. Int J Financ Econ. https://doi.org/10. 1002/ijfe. 1878

Mohsin M, Taghizadeh-Hesary F, Panthamit N et al (2020b) Developing low carbon finance index: evidence from developed and developing economies. Financ Res Lett. https://doi.org/10.1016/j. frl.2020.101520 
Mohsin M, Hanif I, Taghizadeh-Hesary F et al (2021a) Nexus between energy efficiency and electricity reforms: a DEA-Based way forward for clean power development. Energy Policy. https://doi. org/10.1016/j.enpol.2020.112052

Mohsin M, Ullah H, Iqbal N et al (2021b) How external debt led to economic growth in South Asia: a policy perspective analysis from quantile regression. Econ Anal Policy 72:423-437. https://doi. org/10.1016/J.EAP.2021.09.012

Mosser PC (2020) Central bank responses to COVID-19. Bus Econ. https://doi.org/10.1057/ s11369-020-00189-X

Ozoike-Dennis P, Spaling H, Sinclair AJ, Walker HM (2019) SEA, urban plans and solid waste management in kenya: participation and learning for sustainable cities. J Environ Assess Policy Manag. https://doi.org/10.1142/S1464333219500182

Pogorletskiy AI, Pokrovskaia NV (2021) Comparative analysis of fiscal regulation measures of the g20 countries in the era of the coronavirus crisis and in the post-coronavirus perspective. $\mathrm{J}$ Appl Econ Res. https://doi.org/10.15826/vestnik.2021.20.1.002

Sarkodie SA, Owusu PA (2020) Global assessment of environment, health and economic impact of the novel coronavirus (COVID-19). Environ Dev Sustain. https://doi.org/10.1007/s10668-020-00801-2

Shaharuddin A (2020) Guest editors' notes: COVID-19: the pandemic's impacts on the economy and realisation of maqasid al-shariah and islamic finance. J Muamalat Islam Financ Res. https://oi.org/ 10.33102/jmifr.v17i3.278

Song L, Zhou Y (2020) The COVID-19 pandemic and its impact on the global economy: what does it take to turn crisis into opportunity? China World Econ. https://doi.org/10.1111/cwe.12349

Taghizadeh-Hesary F, Taghizadeh-Hesary F (2020) The impacts of air pollution on health and economy in Southeast Asia. Energies. https://doi.org/10.3390/en13071812

Taghizadeh-Hesary F, Yoshino N (2015) Macroeconomic effects of oil price fluctuations on emerging and developed economies in a model incorporating monetary variables. Econ Policy Energy Environ. https://doi.org/10.3280/EFE2015-002005

Taghizadeh-Hesary F, Yoshino N (2019) The way to induce private participation in green finance and investment. Financ Res Lett. https://doi.org/10.1016/j.frl.2019.04.016

Taghizadeh-Hesary F, Yoshino N (2020) Sustainable solutions for green financing and investment in renewable energy projects. Energies. https://doi.org/10.3390/en13040788

Tian W (2021) How china managed the covid-19 pandemic. Asian Econ Pap. https://doi.org/10.1162/ asep_a_00800

Truger A (2020) Reforming EU fiscal rules: more leeway, investment orientation and democratic coordination. Intereconomics. https://doi.org/10.1007/s10272-020-0915-Z

Victor V, Karakunnel JJ, Loganathan S, Meyer DF (2021) From a recession to the COVID-19 pandemic: Inflation-unemployment comparison between the UK and India. Economies. https://doi.org/10. 3390/economies 9020073

Vidya CT, Prabheesh KP (2020) Implications of COVID-19 pandemic on the global trade networks. Emerg Mark Financ Trade. https://doi.org/10.1080/1540496X.2020.1785426

Wang Q, Zhang F (2021) What does the China's economic recovery after COVID-19 pandemic mean for the economic growth and energy consumption of other countries? J Clean Prod. https://doi.org/10. 1016/j.jclepro.2021.126265

Wei X, Han L (2021) The impact of COVID-19 pandemic on transmission of monetary policy to financial markets. Int Rev Financ Anal. https://doi.org/10.1016/j.irfa.2021.101705

Wu B, Monfort A, Jin C, Shen X (2022) Substantial response or impression management? Compliance strategies for sustainable development responsibility in family firms. Technol Forecast Soc Change. https://doi.org/10.1016/j.techfore.2021.121214

Xiang D, Zhang Y, Worthington AC (2021) Determinants of the use of fintech finance among Chinese small and medium-sized enterprises. IEEE Trans Eng Manag. https://doi.org/10.1109/TEM.2020. 2989136

Yang Z, Abbas Q, Hanif I et al (2021) Short- and long-run influence of energy utilization and economic growth on carbon discharge in emerging SREB economies. Renew Energy. https://doi.org/10.1016/j. renene.2020.10.141

Yildirim K, Onder M (2019) Collaborative role of metropolitan municipalities in local climate protection governance strategies: the case of turkish metropolitan cities. J Environ Assess Policy Manag. https://doi.org/10.1142/S1464333219500066 
Zaytsev YK (2020) Monetary and fiscal policy measures during the COVID-19 economic crisis in Russia. Financ Theory Pract. https://doi.org/10.26794/2587-5671-2020-24-6-6-18

Zhuang M, Zhu W, Huang L, Pan WT (2021) Research of influence mechanism of corporate social responsibility for smart cities on consumers' purchasing intention. Libr Hi Tech. https://doi.org/10. 1108/LHT-11-2020-0290

Publisher's Note Springer Nature remains neutral with regard to jurisdictional claims in published maps and institutional affiliations.

\section{Authors and Affiliations}

\section{Baihua Yuan ${ }^{1} \cdot$ Wang Leiling ${ }^{2} \cdot$ Hayot Berk Saydaliev ${ }^{3,4}\left(\mathbb{D} \cdot\right.$ Vishal Dagar $^{5}$. Ángel Acevedo-Duque ${ }^{6}$}

Baihua Yuan

justin_ybh@sina.com

Hayot Berk Saydaliev

h.saydaliev@tsue.uz

Vishal Dagar

dagarvisha199@gmail.com

Ángel Acevedo-Duque

angel.acevedo@autonoma.cl

1 School of Finance, Jiangxi University of Finance and Economics, No.168, East Shuanggang

Road, Nanchang 330013, Jiangxi Province, People's Republic of China

2 Business School, Zhengzhou University, Zhengzhou 450001, China

3 Business School, Suleyman Demirel University, Almaty 040900, Kazakhstan

4 Mathematical Methods in Economics, Tashkent State University of Economics, 100003 Tashkent, Uzbekistan

5 Department of Economics and Public Policy, Great Lakes Institute of Management, Gurgaon 122413, Haryana, India

6 Public Policy Observatory Faculty of Business and Administration, Universidad Autónoma de Chile, Santiago 7500912, Chile 